\title{
Optimising the Environmental Sustainability of Short Rotation Coppice Biomass Production for Energy
}

\author{
Ioannis Dimitriou ${ }^{1}$, Željka Fištrek ${ }^{2 区}$
}

\footnotetext{
${ }^{1}$ Swedish University of Agricultural Sciences, Department of Crop Production Ecology (Inst. för växtproduktionsekologi), Box 7043, Ullsväg 16, SE-75007 Uppsala, Sweden

2 Energy Institute Hrvoje Požar, Department for Renewable Energies and Energy Efficiency, Savska cesta 163, HR-10000 Zagreb, Croatia

$\varangle$ Corresponding author: e-mail: zfistrek@eihp.hr
}

Citation:

DIMITRIOU I, FIŠTREK Ž 2014 Optimising the Environmental Sustainability of Short Rotation Coppice Biomass Production for Energy. South-east Eur for 5 (2): 81-91. DOI: http://dx.doi.org/10.15177/seefor.14-15

\section{Abstract}

Background and Purpose: Solid biomass from short rotation coppice (SRC) has the potential to significantly contribute to European renewable energy targets and the expected demand for wood for energy, driven mainly by market forces and supported by the targets of national and European energy policies. It is expected that in the near future the number of hectares under SRC will increase in Europe. Besides producing biomass for energy, SRC cultivation can result in various benefits for the environment if it is conducted in a sustainable way. This paper provides with an overview of these environmental benefits.

Discussion and Conclusions: The review of existing literature shows that SRC helps to improve water quality, enhance biodiversity, prevent erosion, reduce chemical inputs (fertilizers, pesticides) and mitigate climate change due to carbon storage. To promote and disseminate environmentally sustainable production of SRC, based on existing literature and own project experience, a set of sustainability recommendations for SRC production is developed. In addition to numerous environmental benefits, sustainable SRC supply chains can bring also economic and social benefits. However, these aspects of sustainability are not addressed in this paper since they are often country specific and often rely on local conditions and policies. The sustainable practices identified in this manuscript should be promoted among relevant stakeholder to stimulate sustainable local SRC production.

Keywords: biodiversity, biomass, bioenergy, short rotation crops, water quality, soil quality 


\section{INTRODUCTION}

Biomass plays a key role among renewable energy sources in Europe, accounting for almost $70 \%$ of all renewables, and showing steady growth. It is expected that the demand for wood as fuel for energy (heat and electricity) will increase, driven mainly by market forces and supported by the targets of national and European energy policies [1]. Solid biomass from short rotation coppice (SRC) has been identified with high potential to significantly contribute to European renewable energy targets [2]. The term SRC refers to biomass productions systems cultivated for energy purposes using fast-growing tree species with the ability to resprout from the stumps after harvest. Harvest occurs in short intervals (2-6 years). The management practices for SRC such as soil preparation, weed control, planting, fertilisation, harvest, resemble more those of agricultural annual crops than of forestry, despite that the currently used species in commercial SRC plantations in Europe are tree species. As SRC species, willows and poplars have been predominantly used in Europe, since they are fast-growing with good coppice ability that reach high growth rates even under very short harvest intervals. Other tree species such as black locust and eucalyptus have been also considered for larger implementation as SRC systems for energy. To avoid misunderstandings between SRC and the more general term Short Rotation Forestry (SRF), we need to point out that SRF is a broader term describing forest systems for biomass production not only for energy purposes but also for others. SRF uses also fast-growing tree species and having denser spacing and more intensive management than traditional forestry, and trees are typically harvested after 2 to 25 years depending on the desired end-product. In this context SRC represents a more specialised and intense practice of SRF dedicated mainly for energy purposes.

SRC is a perennial crop grown on agricultural land that differs from arable crops in many ways. SRC plantations will remain in place for a number of years (10-25 years), therefore taking the land out of arable rotations. SRC is much taller than other arable crops since trees can reach c. 5-8 $\mathrm{m}$ at harvest. Moreover, harvest normally occurs in winter or early spring. Once established, no annual soil cultivation is required, and considerably less agrochemical inputs and fertilizers are applied, although herbicides are used during the establishment phase. When grown, SRC plants are deeper rooted and have a high water consumption compared to conventional crops. As a result of the lower intensity and of less agrochemicals, SRC has a considerably lower carbon footprint compared with food or biofuel production from annual arable food crops [3].

SRC for biomass production used for heat and/or electricity is considered as a very promising system to meet the European targets to increase the amount of renewable energy, and SRC cultivation in larger scale could help meet social and economic targets of other EU policies (e.g. EU Rural Development, CAP reform). This combination of technological and political drivers has stimulated the interest and a rapid large-scale shift from "conventional" agricultural crops to SRC has been predicted [1]. This will have positive and negative implications on a range of environmental issues, which this paper will further analyze. An increase of SRC grown on agricultural land is anticipated in areas neighboring power stations or local producers of heat, using biomass as a fuel. In such areas, SRC might need to be cultivated on a substantial fraction of all available agricultural land to fulfill biomass needs for fuel, being simultaneously economically and energy efficient. This, coupled with the above-mentioned special features of SRC will surely affect the landscape and have potential implications for the local water and soil quality, hydrology, carbon storage in soil, and biodiversity.

The aim of this paper is to refer to and analyze above-mentioned aspects of environmental sustainability of SRC production and to provide with a number of thingsto-consider and criteria about SRC practice 
that will enable to optimize SRC cultivation towards an environmentally sustainable local SRC production. We will refer in detail to the impact of SRC on soil quality, water and biodiversity that is referred in the literature, and based on the existing knowledge we will recommend management measures for optimized sustainable SRC production.

\section{IMPACTS OF SRC ON SOIL QUALITY}

The potential effects of SRC on soil quality are usually divided into two large aspects, the first referring to the changes of soil carbon and the second to the changes of the heavy metal concentrations when SRC is cultivated. Mann and Tolbert [4] concluded that soil ecological benefits of SRC can be caused by the following mechanisms that are characteristic for SRC as a crop in arable soils: a) the continuous plant cover intercepts rainfall and decreases erosion potential, b) the increased root development at greater depths stabilizes soil, improves nutrient uptake and reduces leaching losses, and increases organic matter input, c) litter and vegetation intercept surface runoff and enhance infiltration, and d) the cooler soil temperatures decrease the rate of decomposition. These authors suggested that soil ecological benefits of SRC with fast growing tree species were predicted to become detectable already in 3 to 5 years, a period that for a number of other authors is considered rather short. Especially when concerning empirical studies estimating changes in carbon (C) storage in the soil of willow and poplar SRC have provided conflicting results, with most of them reporting increases in C stocks in the topsoil when SRC is cultivated for a number of years [5-8], but also others reporting decreases in $C$ stocks [9-11]. It has been concluded that the site-specific variability in the effects of SRC on the soil $C$ pool is high, that previous studies may not have covered a sufficiently long period to detect significant changes in soil $\mathrm{C}$ stocks, and that the fundamental mechanisms responsible for soil organic $\mathrm{C}$ accumulation in SRC are not well understood. However, when comparing carbon concentrations in the topsoil between SRC grown for a number of years with the respective concentrations in adjacent to SRC arable fields, increased carbon concentrations are found $[12,13]$. The same was reported for the carbon concentrations in subsoil, showing the great potential of SRC for storing carbon in agricultural soils compared to current land uses. The amounts of carbon stored seem to be governed by the initial soil properties, and therefore approaches for the selection of most promising sites for carbon sequestration must be developed.

Another soil quality parameter that has been broadly connected to the positive impacts of SRC cultivation is the reduced trace element concentrations in the soil, mainly for cadmium (Cd) $[14,15]$. Cd entering the food chain from agricultural soils is broadly considered as the most hazardous trace element to human health. The ability of willow trees to take up rather high amounts of $\mathrm{Cd}$ in their shoots, which can be removed from the field at harvest has been proposed as a solution to combine biomass production and remediation of moderately contaminated soils [16]. Based on this feature of SRC, it is common to apply sewage sludge to SRC fields. A supply of trace elements occurs, but several studies and calculations of flows in willow SRC stands suggest that uptake is enough to compensate for this. A reduction of $\mathrm{Cd}$ even after sludge amendment is highly probable, but questionable for other investigated trace elements $[17,18]$. Concerning uptake of other than $\mathrm{Cd}$ trace elements, such as $\mathrm{Cu}, \mathrm{Pb}, \mathrm{Zn}, \mathrm{Cr}, \mathrm{Ni}, \mathrm{As}$, several studies have been conducted and showed positive results concerning uptake in the shoots, but most of these results have been based on experiments in pots or under hydroponic conditions and their results cannot be generalized referring to field conditions [19-22]. Due to the ability of especially willow to take up trace elements from the soil, SRC plantations have been used for phytoremediation of soils and waters containing these hazardous elements. The use of SRC as multi-purpose plantations for 
phytoremediation of contaminated soils (e.g. extraction of $\mathrm{Cd}, \mathrm{Zn}$ and other heavy metals, and degradation of organic compounds) can be combined when biomass is produced in such sites and improve the soil quality of moderately contaminated arable land, but also of marginal land that can be returned to agricultural production after SRC cultivation for a number of years [23].

\section{IMPACT OF SRC ON WATER}

The two issues that are mostly brought up when discussing the SRC impact on water are SRCs impact on water balances and on groundwater quality. The decision behind using willow and poplar as SRC for production of biomass for energy was among other reasons based on their characteristic to be fast-growing producing higher biomass compared to other tree species, especially in central and northern Europe. Increased biomass accumulation has been linked with high water use, especially in warmer climates. Willows in particular are known to grow in places with high water availability such as river banks. Coupled with the fast-growing feature of SRC, fears for high water use and consequent concerns about the effects on local hydrological balances and flow to neighbouring streams/rivers have been expressed in several reports predicting future biomass supply from agriculture $[24,25]$.

A large number of studies have been performed to estimate the evapotranspiration in SRC fields with the aim to evaluate expected changes in water balances in relation to other land uses. For willows, most of them were primarily conducted in Sweden, since it was there that cultivation of SRC for biomass was initiated and then commercially practiced. Similar research on poplars has been conducted in a range of countries with more temperate climate than Sweden such as in Germany and the UK, where poplar has been considered as more appropriate species than willow grown as SRC, gaining large interest during the last years. From the several estimates for evapotranspiration for poplar and willow, there seem to be variations in the figures reported. For irrigated and fertilised willow SRC grown in clay in south Sweden for four years, Persson and Lindroth [26] simulated seasonal (May-November) evapotranspiration between 360-404 mm. Persson [27] estimated that the average seasonal evapotranspiration (May-October) from six fields in different locations in south Sweden areas was $435 \mathrm{~mm}$, confirming in a way the previous findings. For SRC poplar fields, Bungart and Bungart and Hüttl [28] estimated mean annual transpiration rates between 1996-2002 at the Lusatian mining region in Germany equal to 266 and $241 \mathrm{~mm}$, for two different poplar clones, respectively (Beaupré, Populus trichocarpa $\times$ P. deltoides and Androscoggin, P. maximowiczii). Evapotranspiration was 404 and $373 \mathrm{~mm}$, respectively. Annual evapotranspiration of $351 \mathrm{~mm}$ and $360 \mathrm{~mm}$ for a 3- and a 9-year old SRC poplar plantation, respectively, located in Neuruppin, Germany, has been calculated by Knur et al. [29]. In the UK, Hall [30] estimated that ca. $600 \mathrm{~mm}$ will be used by SRC willow in a clay soil which receives precipitation of $700 \mathrm{~mm}$. According to Hall [30] this corresponds to an annual evapotranspiration of about $500 \mathrm{~mm}$. From the above it can be assumed that there has been vast variations for the estimated evapotranspiration of SRC and that safe predictions of evapotranspiration from an SRC stand cannot be granted.

When comparing the evapotranspiration of SRC with willow and poplar, in most cases it is significantly higher than arable crops and lower than other forest $[27,30,31]$. In contrast to this, Hall et al. [32] indicated that in case of dry summers when there is significant water deficit, the water use of poplar SRC will probably be considerably less than that of coniferous forest and closer to that of grassland. Sensitivity of willow SRC to dry summers have been also reported by Linderson et al. [33], where transpiration rates varied between willow clones and were equal to $100-325 \mathrm{~mm}$. Therefore, the levels of water consumption of SRC in relation to 
other crops grown in the same area seem to depend on site-specific factors as soil type, precipitation and others, and might vary from case to case, although SRC seem to have higher evapotranspiration than arable crops in most cases. Concerning the impact on local level, modelling exercises conducted by Stephens et al. [31] indicated reductions of $10-15 \%$ of the hydrologically effective rainfall in SRC fields compared to arable crops in the UK. Despite this, the authors claimed that the effect on hydrology to the catchment level would be minimal, after extrapolations based on the model results obtained and the assumption that 2500 ha SRC will be planted in an area of $40 \mathrm{~km}$ radius from a biomass-driven power plant. This was due to the fact that the mean reduction in hydrologically effective rainfall for the catchment area would be ca. $0.5 \%$ of the mean annual amount, which would be only a very minor portion, compared to the respective effect of cereals.

SRC is generally considered as a crop that improves the water quality in a certain area due to the management practices that has been mentioned above for this crop [25]. Almost all water quality research has been conducted concerning leaching of nutrients and not determination of chemical compounds as pesticides in the groundwater, since the use of pesticides is limited. Fertilization in willow SRC is recommended and in Northern Ireland the recommendations are $120-150 \mathrm{~kg}$ nitrogen $(\mathrm{N})$ per hectare and year. In Sweden the recommendations is ca. $100 \mathrm{~kg} \mathrm{~N}$ per hectare and year, but not after the second year of growth when no fertilisation occurs. In general, SRC fertilisation recommendations can be considered rather moderate compared to respective ones for arable crops [34]. However, the fact that fertilisation to SRC fields cannot be applied every year but usually only every year after harvest due to the nature of the crop (high stems that do not allow the available equipment to apply fertiliser every year) makes the applied amounts of nutrients relatively high. Bergström and Johansson [35] measured very low $\mathrm{N}$ concentrations (less than
$1 \mathrm{mg} / \mathrm{l} \mathrm{N}$ ) in the groundwater of an intensively fertilised willow SRC field in south Sweden. Measurements of $\mathrm{N}$ in the surface groundwater at the same field for a period of eight years with average annual application rates of $112 \mathrm{~kg} \mathrm{~N} / \mathrm{ha}$ showed that $\mathrm{N}$ concentrations remained below $1 \mathrm{mg} / \mathrm{N}$ for the whole period except during the year of establishment [36]. These results came in agreement with Mortensen et al. [37] that measured close to zero $\mathrm{N}$ concentrations in drainage water from Danish SRC fields, except for the establishment year. Dimitriou et al. [38] reported that the differences in the nitrogen leaching from commercial willow SRC fields in Sweden compared to adjacent arable fields were of a factor of 20 (lower for SRC), indicating striking differences. Due to this ability of utilizing $\mathrm{N}$ in combination with low $\mathrm{N}$ leaching to the groundwater, SRC has been used to treat and utilize N-rich wastewaters such as municipal wastewater or landfill leachate, but also solid residues such as sewage sludge (combined with the ability to take up heavy metals as analysed above - [23]). There have been extensive research evaluating leaching of $\mathrm{N}$ but also of $\mathrm{P}$ from such practices when very high $\mathrm{N}$ amounts have been applied trying to optimize the systems (e.g. up to $300 \mathrm{~kg} \mathrm{~N} /$ ha $\mathrm{yr}$ ), with the results very low leaching from SRC [39-42].

All the above show the potential for using SRC in intensively managed agricultural areas to reduce nutrient leaching either by replacing existing crops or by using SRC as buffer zones between intensively managed arable land and water bodies to reduce surface run off and groundwater leaching.

\section{IMPACT OF SRC ON BIODIVERSITY}

Concerning the impact of SRC on biodiversity, comparison between SRC and alternative uses in arable land has been of great importance when considering the reduction of biodiversity in European landscapes. Protection and increase of biodiversity is a political commitment set by the European Union, and 
therefore it would be of key importance if biodiversity could be increased within the stand and/or in the surroundings when SRC replaces other crops in agricultural areas intensively managed. For such comparisons, it is interesting to consider the reports of Baum S. et al. [43] about the impact of SRC on phytodiversity, where it is reported that there are indications about increased biodiversity in SRC in comparison with other arable crops. Several authors reported an increased number of species in SRC compared to neighbouring arable land [44-46] but in most cases rare or endangered (redlisted) species are not found. The few rare or endangered species occasionally found in SRC plantations are predominantly light demanding pioneer species recorded in the first years of a plantation and disappearing with increasing plantation age. Weih et al. [47] found not a single rare species in 21 young poplar stands grown in Sweden, however, Kroiher et al. [48] recorded a higher number of rare species in SRC plantations in northern Germany, having their main distribution in nutrient-poor habitats. The relatively high occurrence of rare species is probably related to the great tree distances in poplar plantations and the resulting favourable light and temperature conditions. The number of red list species declined with increasing canopy closure of the poplars after two years, implying that the shortening of rotation time probably supports the establishment and survival of endangered species. It has been also mentioned that plantation size and shape seem to be important for biodiversity, with higher species numbers recorded at the edge of a plantation than within it. Baum et al. [43] reported that despite the lack of long-term studies that would enable better understanding on how SRC affects phytodiversity in time and space, there are indications that it would be increased if SRC is planted in areas dominated by agriculture or coniferous forest. The authors also identified areas where SRC establishment might negatively affect phytodiversity, especially habitats of threatened species such as undisturbed peat land, forest wetlands, or areas adjacent to lakes or rivers.
Schulz et al. [49] claim that research studies for animal diversity in SRC has been conducted mostly for birds and ground beetles, and that more research for invertebrates is needed. Vertebrate diversity, equated with species richness, differs considerably in SRC in comparison to arable fields; whereas bird diversity in SRC is higher than in agricultural cropland [50-52] higher diversities of ground beetles have been found in arable fields. Britt et al. [45] found significantly more ground beetle species in arable fields than in poplars on British sites, and the same was observed in North German SRCs than on the neighbouring intensively farmed agricultural crop land [4952]. For mammals, little research has been conducted, but species observed in SRC plantations in England included 17 mammals [53] suggesting that SRC provided a more attractive habitat for small mammals than arable land, with older coppices being more attractive. The varying results for zoodiversity are explained on the dependency of animal diversity on a number of factors such as the age of the plantation, the tree species/clone, the plantation size, the habitat structures and the location of the plantation (surroundings and other uses). The influence of the surrounding landscapes on the diversity of SRCS and the influence of SRCS on the diversity of the surrounding landscapes need to be considered, and the importance of the decision for locating the plantations is very critical for optimizing the obtained biodiversity. Aspects of deciding about the how and where an establishment of SRC should take place in certain landscapes, and their consequences, are developed in the next chapter.

\section{CRITERIA AND RECOMMENDATIONS FOR SUSTAINABLE SRC PRODUCTION}

The criteria to characterize SRC as sustainable can be fulfilled if a number of general recommendations to optimize SRC practice towards sustainable production of SRC can be developed. These have to be based on the obtained research results, combined 
with practical issues that will enable highest economic profit. In an effort to list all these recommendations for SRC management/practice to increase positive impacts and decrease negative impacts on the environment, the most important recommendations considering biodiversity, soil and water issues are presented below.

Considering the impact on soil:

- SRC could be cultivated in fields with low initial soil organic matter content to increase this content and with this the fertility and carbon storage of the soil.

- SRC should be cultivated especially in areas with a high risk of erosion, e.g. with relief of less than $13 \%$ or open landscapes, to lower the loss of fertile topsoil and nutrients by water and wind.

- Application of municipal residues such as sewage sludge for recycling of nutrients to SRC can be encouraged, since SRC can contribute to prevent nutrient losses and can extract heavy metals efficiently.

- SRC should be used to remediate soils with increased $\mathrm{Cd}$ concentrations caused e.g. by the long-term use of Cdcontaining P-fertilizers or other sources of environmental pollution.

- SRC fields should be established at the same location for at least three cutting cycles to achieve soil quality improvements concerning carbon storage and Cd uptake.

- SRC should be harvested in winter when soil is frozen to avoid soil compaction and corrosion risks due to alkaline inputs from fresh plant material in the boilers.

Considering the impact on water:

- SRC could be cultivated in fields located close to $\mathrm{N}$ sources (e.g. animal farms, $\mathrm{N}$ vulnerable zones, wastewater treatment plants etc) to decrease $\mathrm{N}$ outflow to adjacent water bodies.

- SRC should be cultivated in areas where low groundwater level is anticipated (potentially flooded areas and areas near water bodies which can potentially flood).

- Application of municipal residues such as sewage sludge for recycling of nutrients does not affect water quality, and should therefore be encouraged.

- More frequent harvests lead to a higher average groundwater recharge, and therefore should be encouraged to ameliorate possible negative impact of groundwater recharge reductions.

Considering the reported impact on phytodiversity:

- The establishment of SRCs in areas with high ecological status should be avoided (e.g. areas with protection status for nature conservation, areas with rare species, wetlands, peat bogs, swamps).

- High structural heterogeneity provides habitats for different plant requirements and thus increases diversity. High structural diversity at one SRC location can be achieved by:

i) Planting different tree species and clones;

ii) Harvesting at different times so that the trees have different rotation ages within one area.

- Edges of SRCs have great species diversity, and planting several smaller plantations instead of one big SRC is advised because smaller plantations have longer edges for their size than larger ones. If that is not possible, planting long rectangular plantations can provide more benefits considering increased phytodiversity.

- An increase in forest ground species can be achieved by reducing the irradiance reaching the ground vegetation. This can be done by long rotation periods, high plant densities and planting willow instead of poplar. Another possibility is aligning planting rows in the east-west direction to reduce radiation reaching ground vegetation by shading the planted crop.

Considering the impact on zoodiversity:

- Where possible SRCs should be designed with a large edge to interior ratio.

- A mix of varieties and clones should be used.

- Rotational harvesting in mixed age-class blocks should be preferred. 
- Huge blocks of SRC should be seperated, e.g. by rides and hedges.

- Where possible, and in case of growing willow, planting of willow hybrids (Salix sp.) with a range of flowering times should be preferred.

- The use of pesticides should be limited if highest zoodiversity is to be achieved.

- A percentage of the SRC area should be reserved for small habitats like strips of grass and stepped wood boundaries.

- There should be no SRCs in high wildlifevalue habitats like wetlands, wet meadows, set asides, dry fallows, seminatural grassland.

The balance between maximum environmental benefits and maximum attained biomass production from SRC is a big challenge that all stakeholders involved in SRC cultivation (farmers, decision-makers, researchers, and others) should deal with. Despite all the abovementioned expected positive environmental impact of SRC, farmers need to be convinced to cultivate the crop, and this is typically achieved when the economic profit from the cultivation of a new crop such as SRC is equal to or higher than that of other "established" or "conventional" crops. Such issues are dealt with in Köhn [54], Dimitriou et al. [55]. To encourage farmers to grow SRC instead of other crops in order to achieve environmental benefits, decision-makers should be prepared to contribute with direct or indirect incentives to the farmers. For instance, a potential economic compensation to the farmers could be a form of "reward" for those helping to fulfill national and European environmental goals already set and simultaneously keeping agricultural land into production. Such issues concerning the added value of SRC cultivation, when at the same time important environmental goals are achieved, should be one of the drivers for sustainable SRC cultivation, besides or in combination with drivers for producing biomass for energy to achieve renewable energy commitments.

\section{CONCLUSIONS}

The extensive review of the existing research on the impact of SRC production on the environment has shown that a number of benefits could be achieved with SRC. If the recommendations developed within this paper are followed, SRC production can show significant improvement of soil and water quality, enhance biodiversity and diversify the landscape. It is important to note that a balance between the potential maximum profit for the farmer and the maximum environmental advantages for the society need to be achieved at a specific area. Before establishing a SRC plantation, all related aspects and obtained research findings need to be considered, in combination with the site-specific features of the available sites towards a sustainable SRC cultivation.

\section{Acknowledgement}

The paper is supported by European Commission through Intelligent Energy for Europe Programme within the project SRCplus, which is gratefully acknowledged. The content of this paper does not reflect the official opinion of the European Union. Responsibility for the information and views expressed in the paper lies entirely with the authors. 


\section{REFERENCES}

1. EEA 2007 Estimating the environmentally compatible bioenergy potential from agriculture. European Environment Agency (EEA), Copenhagen, Denmark, Technical report No 12/2007, 134 p. URL: http://www.eea.europa. eu/publications/technical report_2007 12 (10 August 2014)

2. STYLES D, JONES M 2007 Energy crops in Ireland: Quantifying the potential life-cycle greenhouse gas reductions of energy-crop electricity. Biomass Bioenerg 31 (11-12): 759-772. DOI: http://dx.doi. org/10.1016/j.biombioe.2007.05.003

3. HELLER MC, KEOLEIAN GA, MANN MK, VOLK TA 2004 Life cycle energy and environmental benefits of generating electricity from willow biomass. Renew Energ 29 (7): 1023-1042. DOI: http:// dx.doi.org/10.1016/j.renene.2003.11.018

4. MANN L, TOLBERT V 2000 Soil sustainability in renewable biomass plantings. Ambio 29: 492498. DOI: http://dx.doi.org/10.1579/0044-744729.8.492

5. MATTHEWS RB, GROGAN P 2001 Potential $\mathrm{C}$-sequestration rates under short-rotation coppiced willow and Miscanthus biomass crops: a modelling study. Aspects Appl Biol 65: 303-312

6. KAHLE P, HILDEBRANT E, BAUM C, BOELCKE B 2007 Long-term effects of short rotation forestry with willows and poplar on soil properties. Arch Agr Soil Sci 53 (6): 673-682. DOI: http://dx.doi. org/10.1080/03650340701648484

7. GRIGAL DF, BERGUSON WE 1998 Soil carbon changes associated with short-rotation systems. Biomass Bioenerg 14 (4): 371-377. DOI: http:// dx.doi.org/10.1016/50961-9534(97)10073-3

8. SCHMITT AK, TISCHER S, ELSTE B, HOFMANN B, CHRISTEN O 2010 Effect of energy forestry on physical, chemical and biological soil properties on a chernozem in continental dry climate conditions in central Germany. J Kulturpflan 62 (6): 189-199

9. COLEMAN MD, ISEBRANDS JG, TOLSTED DN, TOLBERT VR 2004 Comparing soil carbon of short rotation poplar plantations with agricultural crops and woodlots in North Central United States. Environ Manage 33 (1): 299-308. DOI: http:// dx. doi.org/ 10.1007/s00267-003-9139-9

10. SARTORI F, LAL R, EBINGER MH, EATON JA 2007 Changes in soil carbon and nutrient pools along a chronosequence of poplar plantations in the Columbia Plateau, Oregon, USA. Agric Ecosyst Environ 122 (3): 325-339. DOI: http://dx.doi. org/10.1016/j.agee.2007.01.026

11. GARTEN CT, WULLSCHLEGER SD, CLASSEN AT, 2011 Review and model-based analysis of factors influencing soil carbon sequestration under hybrid poplar. Biomass Bioenerg 35 (1): 214-226. DOI: http://dx.doi.org/10.1016/j.biombioe.2010.08.013

12. DIMITRIOU I, MOLA-YUDEGO $B$, ARONSSON $P_{1}$ ERIKSSON J 2012 Changes in organic carbon and trace elements in the soil of wi-llow short-rotation coppice plantations. Bioenerg Res 5 (3): 563-572. DOI: http://dx.doi.org/ 10.1007/s12155-012-92151

13. KAHLE P, BAUM C, BOELCKE B, KOHL J, ULRICH R 2010 Vertical distribution of soil properties under short-rotation forestry in Northern Germany. J Plant Nutr Soil Sc. 173 (5): 737-746. DOI: http:// dx.doi.org/10.1002/jpln.200900230

14. RIDDEL-BLACK DM 1994 Heavy metal uptake by fast growing willow species. In: Aronsson P, Perttu K (eds) Proceedings of Willow vegetation filters for municipal wastewaters and sludges. A biological purification system, Sweden, 5-10 June 1994. Swedish University of Agricultural Sciences, Uppsala, Sweden, Report 50, pp 133-144

15. KLANG- WESTIN E, ERIKSSON J 2003 Potential of Salix as phytoextractor for $\mathrm{Cd}$ on moderately contaminated soils. Plant Soil 249 (1): 127-137. DOI: http://dx.doi.org/10.1023/A:1022585404481

16. BAUM C, LEINWEBER P, WEIH M, LAMERSDORF N, DIMITRIOU I 2009 Effects of Short Rotation Coppice with willows and poplar on soil ecology. Landbauforsch vTI Ag 59 (3): 183-196

17. DIMITRIOU I, ERIKSSON J, ADLER A, ARONSSON P, VERWIJST T 2006 Fate of heavy metals after application of sewage sludge and wood-ash mixtures to short-rotation willow coppice. Environ Pollut 142 (1): 160-169. DOI: http://dx.doi. org/10.1016/j.envpol.2005.09.001

18. PULFORD ID, RIDDEL-BLACK D, STEWART C 2002 Heavy metal uptake by willow clones from sewage sludge-treated soil: The potential for phytoremediation. Int J Phytoremediat 4 (1): 59-72. DOI: http://dx.doi. org/10.1080/15226510208500073 
19. ROBINSON BH, MILLS TM, PETIT D, FUNG LE, GREEN SR, CLOTHIER BE 2000 Natural and induced Cdaccumulation in poplar and willow: Implications for phytoremediation. Plant Soil 227 (1-2): 301-306. DOI: http://dx.doi.org/10.1023/A:1026515007319

20. GRANEL T, ROBINSON B, MILLS T, CLOTHIER B, GREEN S, LUNG L $2002 \mathrm{Cd}$ accumulation by willow clones used for soil conservation, stock fodder, and phytoremediation. Aust J Soil Res 40 (8): 13311337. DOI: http://dx.doi.org/10.1071/SR02031

21. LANDBERGER T, GREGER M 2002 Interclonal variation of heavy metal interactions in Salix viminalis. Environ Toxicol Chem 21 (12): 2669-2674. DOI: http://dx.doi.org/10.1002/etc.5620211220

22. VYSLOUZILOVA M, TLUSTOS P, SZAKOVA J 2003 Cd and zinc phytoextraction potential of seven clones of Salix spp. planted on heavy metal contaminated soils. Plant Soil Environ 49 (12): 542-547

23. DIMITRIOU I, ARONSSON P 2005 Willows for energy and phytoremediation in Sweden. Unasylva 221 (56): 46-50

24. EPPLER U, PETERSEN J, COUTURIER C 2007 Short Rotation Forestry, Short Rotation Coppice and Perennial Grasses in the European Union: Agro-environmental aspects, present use and perspectives. Background paper for a joint expert workshop of JRC/EEA/Rothamsted Research in Rothamsted, October 2007, pp 95-133. URL: http://iet.jrc.ec.europa.eu/remea/sites/remea/files/ files/documents/events/background_paper_final_ draft.pdf (15 May 2014).

25. EEA 2008 A review of the possible impact of biomass production from agriculture on water. Background paper for the conference "WFD meets CAP - Looking for a consistent approach". European Environment Agency (EEA), Copenhagen, Denmark, 20 p. URL: http://icm. eionet.europa.eu/ETC_Reports/Biomass_WFD report V7 final260108-2.pdf (6 July 2014)

26. PERSSON G, LINDROTH A 1994 Simultaneous evaporation from short-rotation forest: variations within and between seasons. J Hydrol 156 (14): 21-45. DOI: http://dx.doi.org/10.1016/00221694(94)90069-8

27. PERSSON G 1995 Willow stand evapotranspiration simulated for Swedish soils. Agr Water Manage 28 (4): 271-293. DOI: http://dx.doi.org/10.1016/03783774(95)01182-X
28. BUNGART R, HÜTTL FJ 2004 Growth dynamics and biomass accumulation of 8-year-old hybrid poplar clones in a short-rotation plantation on a clayey-sandy mining substrate with respect to plant nutrition and water budget. Eur J For Res 123 (2): 105-115. DOI: http://doi.org/10.1007/ s10342-004-0024-8

29. KNUR L, MURACH D, MURN Y, BILKE G, MUCHIN A, GRUNDMANN P, EBERTS J, SCHNEIDER U, GRÜNEWALD $\mathrm{H}$ ， SCHULTZE B, QUINKENSTEIN A, JOCHHEIM H 2007 Potentials, economy and ecology of a sustainable supply with wooden biomass. In: 15th European Biomass Conference \& Exhibition, Berlin, Germany, 7-11 May 2007. ETARenewable Energies, Florence, Italy

30. HALL RL 2003 Short rotation coppice for energy production hydrological guidelines. URN 03/883, DTI, 21 p. URL: http://nora.nerc.ac.uk/2631/1/ HallShortRotationReport.pdf (10 May 2014)

31. STEPHENS W, HESS T, KNOX J 2001 Review of the effects of energy crops on hydrology. Institute of Water and Environment, Cranfield University, Silsoe, Bedford MK45 4DT, UK, 59 p. URL:http://dspace.lib.cranfield.ac.uk:8080/ bitstream/1826/3368/1/Review\%20of\%20the $\% 20$ effects $\% 20$ of $\% 20$ energy $\% 20$ crops $\% 20$ on $\% 20$ hydrology-2001.pdf (10 May 2014)

32. HALL RL, ALLEN SJ, ROSIER PTW, HOPKINS R 1998 Transpiration from coppiced poplar and willow measured using sap-flow methods. Agr Forest Meteorol 90 (4): 275-90. DOI: http://dx.doi. org/10.1016/S0168-1923(98)00059-8

33. LINDERSON M, IRITZ Z, LINDROTH A 2007 The effect of water availability on stand-level productivity, transpiration, water use efficiency and radiation use efficiency of field-grown willow clones. Biomass Bioenerg 31 (7): 460-468. DOI: http://dx.doi.org/10.1016/j.biombioe.2007.01.014

34. ARONSSON P, ROSENQVIST H, DIMITRIOU I 2014 Impact of nitrogen fertilization to short-rotation willow coppice plantations grown in Sweden on yield and economy. Bioenergy Research 7 (3): 993 1001. DOI: http://dx.doi.org/10.1007/s12155-0149435-7

35. BERGSTRÖM L, JOHANSSON R 1992 Influence of fertilized short-rotation forest plantations on nitrogen concentrations in groundwater. Soil Use Manage 8 (1): 36-40 http://dx.doi. org/10.1111/j.1475-2743.1992.tb00890.x 
36. ARONSSON PG, BERGSTROM LF, ELOWSON SNE 2000 Long-term influence of intensively cultured shortrotation Willow Coppice on nitrogen concentrations in groundwater. J Environ Manage 58 (2): 135-145. DOI: http://dx.doi.org/10.1006/jema.1999.0319

37. MORTENSEN J, NIELSEN KH, JØRGENSEN U 1998 Nitrate leaching during establishment of willow (Salix viminalis) on two soil types and at two fertilization levels. Biomass Bioenerg 15 (6): 457-466. DOI: http://dx.doi.org/10.1016/509619534(98)00056-7

38. DIMITRIOU I, MOLA-YUDEGO B, ARONSSON P 2012 Impact of willow Short Rotation Coppice on water quality. Bioenergy Research 5 (3): 537-545 http:// dx.doi.org/10.1007/s12155-012-9211-5

39. SUGIURA A, TYRELL SF, SEYMOUR I, BURGESS PJ 2008 Water Renew systems: wastewater polishing using renewable energy crops. Water Sci Technol 57 (9): 1421-1428. DOI: http://dx.doi.org/10.2166/ wst.2008.240

40. WERNER A, MCCRACKEN A 2008 The use of Short Rotation Coppice poplar and willow for the bioremediation of sewage effluent. Asp App Biol 90, Biomass and Energy Crops III: 317-324

41. ARONSSON P, DAHLIN T, DIMITRIOU I, 2010 Treatment of landfill leachate by irrigation of willow coppice - Plant response and treatment efficiency. Environ Pollut 158 (3): 795-804. DOI: http://dx.doi. org/10.1016/j.envpol.2009.10.003

42. DIMITRIOU I, ARONSSON P 2011 Wastewater and sewage sludge application to willows and poplars grown in lysimeters - Plant response and treatment efficiency. Biomass Bioenerg 35 (1): 161-170. DOI: http://dx.doi.org/10.1016/j.biombioe.2010.08.019

43. BAUM S, WEIH M, BUSCH G, JACOBS S, SCHMIDTWALTER P, LAMERSDORF N 2009 A review of the impacts of Short Rotation Coppice cultivation on water issues. Landbauforsch VTI Ag 3: 197-206

44. AUGUSTSON A, LIND A, WEIH M 2006 Floristik mångfald i Salix-odlingar. Sven Bot Tidskr 100: 5258

45. BRITT C, FOWBERT J, McMILLAN SD 2007 The ground flora and invertebrate fauna of hybrid poplar plantations: results of ecological monitoring in the PAMUCEAF project. Aspects of Applied Biology 82: 83-89
46. PERTTU KL 1998 Environmental justification for short-rotation forestry in Sweden. Biomass Bioenerg 15 (1):1-6. DOI: http://dx.doi.org/10.1016/S09619534(98)00014-2

47. WEIH M, KARACIC A, MUNKERT H, VERWIJST T, DIEKMANN M 2003 Influence of young poplar stands on floristic diversity in agricultural landscapes (Sweden). Basic Appl Ecol 4 (2): 149-156. DOI: http://dx.doi.org/10.1078/1439-1791-00157

48. KROIHER F, BIELEFELD J, BOLTE A, SCHULTER M 2008 Die Phytodiversität in Energieholzbeständen: erste Ergebnisse im Rahmen des Projektes NOVALIS (in German). Arch Forstwesen Landschaftsökol 42:158165

49. SCHULZ U, BRAUNER O, GRUß 2009 Animal diversity on Short Rotation Coppices. Landbauforsch VTI Ag 3: 171-182

50. SAGE R, CUNNINGHAM M, BOATMAN N 2006 Birds in willow short-rotation coppice compared to other arable crops in central England and a review of bird census data from energy crops in the UK. Ibis 148 (1): 184-197. DOI: http://dx. doi.org/10.1111/j.1474919X.2006.00522.x

51. ANDERSON GQA, HASKINS LR, NELSON SH 2004 The effects of bioenergy crops on farmland birds in the United Kingdom: a review of current knowledge and future predictions. In: Biomass and agriculture: sustainability, markets and policies; OECD workshop, Vienna, Austria, 10-13 June 2003. Organisation for Economic Co-operation and Development (OECD), Paris, France, pp 199-218

52. BERG A 2002 Breeding birds in short-rotation coppices on farmland in central Sweden: the importance of Salix height and adjacent habitats. Agr Ecosyst Environ 90 (3): 265-276. DOI: http:// dx.doi.org/10.1016/S0167-8809(01)00212-2

53. ROWE RL, STREET NR, TAYLOR G 2007 Identifying potential environmental impacts of large-scale deployment of dedicated bioenergy crops in the UK. Renew Sust Energ Rev 13 (1): 271-290. DOI: http:// dx.doi.org/10.1016/..rser.2007.07.008

54. KÖHN J 2009 Socio-economics in SRC - a review on concepts and the need for transdisciplinary research. Landbauforsch VTI Ag 3: 223-232

55. DIMITRIOU I, ROSENQVIST H, BERNDES G 2011 Slow expansion and low yields of willow short rotation coppice in Sweden; implications for future strategies. Biomass Bioenerg 35 (11): 4613-4618. DOI: http:// dx.doi.org/10.1016/j.biombioe.2011.09.006 